ENTREPRENEURSHIP AND SUSTAINABILITY ISSUES

ISSN 2345-0282 (online) http://jssidoi.org/jesi/ 2020 Volume 8 Number 1 (September)

http://doi.org/10.9770/jesi.2020.8.1(1)

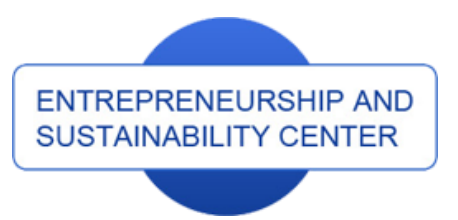

Publisher

http://jssidoi.org/esc/home

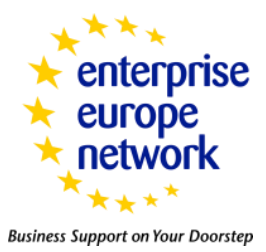

CASPA

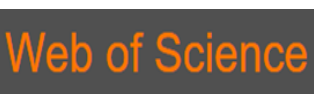

1) Clarivate

\title{
THE SCOPE OF DIVERSIFICATION OF THE WAREHOUSE SPACE MARKET IN A REGIONAL CONFIGURATION*
}

\author{
Adam Marcysiak \\ Siedlce University of Natural Sciences and Humanities, Faculty of Social Science, \\ Konarskiego 2, 08-110 Siedlce, Poland \\ E-mails: adam.marcysiak@uph.edu.pl
}

Received 18 January 2020; accepted 10 June 2020; published 30 September 2020

\begin{abstract}
The purpose of the study is an attempt to show the scope of diversity occurring in the warehouse space market in a regional system. The size of the existing warehouse space, the scope of its use and the level of rents were analysed. The basic factors affecting the location of such objects in a given area were also indicated. Poland has the largest warehouse space market among the countries of Central and Eastern Europe (CEE). The amount of warehouse space in Poland is increasing every year. In 2014, it amounted to 8.5 million m2 and in the third quarter of 2019, 17.7 million $\mathrm{m} 2$. Currently, over $83 \%$ of the warehouse space market is concentrated in five main regions. These include the Warsaw region, Central Poland, Upper Silesia, Wrocław and the Poznan region. These centres, having a large population, generate significant demand for goods stored in warehouses. At the same time, locations around Szczecin, Tri-City, Rzeszów and Lublin are becoming the subject of growing interest of many developers and tenants. The increase in their investment potential is influenced by the availability of labour as well as differences in the level of employees' remuneration and the availability of land at attractive prices.
\end{abstract}

Keywords: scope of diversity; regional diversity; location factors; logistics operators; sustainable development; warehouse space management; supply chain

Reference to this paper should be made as follows: Marcysiak, A. 2020. The scope of diversification of the warehouse space market in a regional configuration. Entrepreneurship and Sustainability Issues, 8(1), 10-23. http://doi.org/10.9770/jesi.2020.8.1(1)

JEL Classifications: L22, L26, O32, Q55Q56

Additional disciplines: management and quality

\footnotetext{
* This research was carried out under the research theme No. 80/20/B financed from by a science grant provided by the Ministry of Science and Higher Education of Poland.
} 


\section{ENTREPRENEURSHIP AND SUSTAINABILITY ISSUES}

ISSN 2345-0282 (online) http://jssidoi.org/jesi/ 2020 Volume 8 Number 1 (September) http://doi.org/10.9770/jesi.2020.8.1(1)

\section{Introduction}

The warehouse and logistics market is the most dynamically developing real estate sector in Poland. Only during five years the area of real estate doubled. In the first half of the year 2014 the whole resources of the modern warehouse area equaled not much over $8 \mathrm{mln} \mathrm{m} 2$. However, growing demand on warehouse and logistics areas immediately transferred to revival of the market. In 2017 and 2018, respectively, objects of $2.3 \mathrm{mln} \mathrm{m} 2$ and $2.2 \mathrm{mln} \mathrm{m} 2$ were put into service. The data from 2019 indicate the continuation of this upward trend (Dołęga, 2019).

Polish market of warehouse space is interesting for foreign investors. The biggest and the best known in the world companies decide to place their main transshipment and logistics centres in Poland. These decisions are stimulated by factors such as: good location, constantly developing transport infrastructure and low operation costs (Szymonik, Chudzik, 2018). Taking into consideration the availability of unoccupied parcels and work force, the investors' interest transfers into the fast growth of warehouse space and high activity of developers not only in the main markets (Lin et al., 2018; Singh et al., 2018). This creates new places of work and fosters development of regions.

Poland is included into a group of investment leaders in the Central and Eastern European region (CEE). In 2018 the whole value of investment transactions in the market of commercial real estate was 13.2 bln Euro, from which Poland had 7.3 bln Euro (Trzysło, 2019).

An important part of the investment market is the market of warehouse space. In 2018 the value of warehouse transactions reached 1.8 bln Euro and Poland was third in the list of the most often chosen places in Europe to set up or move a warehouse. Poland was overtaken only by Holland and, the biggest European market, Germany. As the result every tenth square meter of warehouse area was rented in our country.

One of the lowest rents in Europe are among some factors encouraging people to rent warehouse space in Poland. Geographic location at the intersection of the North-South, and the East-West trade routes is another strong point. Additionally, our warehouse market is characterised by the high standard and good equipment of objects.

In Poland, foreign investors dominate the market of warehouse space. During the last three years $70 \%$ of the invested in Poland capital has come from the USA, South Africa, Germany and Great Britain. Polish capital is marginal, not only in comparison with Western European, but also with Central European countries.

The development of infrastructure plays an important role in the location of warehouses. The biggest aggregation of largescale warehouse objects one can see in the neighbourhood of the A1 and A2, and A1 and A4 motorway intersections. The area around Warsaw are other important warehouse centre due to its central location and the capital city status. Also the areas through which expressways run are becoming more and more important. Potential tenants have a wide range of choices because of the regional differentiation in Poland.

\section{The warehouse as an element of the supply chain - literature review}

The warehouse is an important element in the supply chain. It is defined as a functional and organizational unit created for storing material goods (supplies) in a special area of warehouse building. Storage can consist of material stocks, raw materials, semi-finished products and goods which temporarily are not in demand. To store all of them, special conditions and methods are necessary, according to their individual physiochemical properties (Krzyżaniak, Niemczyk, Majewski, Andrzejczyk, 2014).

The warehouse in the supply chain is the main element combining supplies with production and the market (Makaci et al., 2017; Ben Moussa et al., 2019). Receiving goods, their periodic storage and conveying them to the following links of rotation are its functions (Galińska, 2016). However, there are two basic functions of a warehouse, independent on its placement in the organizational structure of enterprise, that is the function of stock protection, which has a static character, and material handling (manipulation function) concerning the time of 


\section{ENTREPRENEURSHIP AND SUSTAINABILITY ISSUES}

ISSN 2345-0282 (online) http://jssidoi.org/jesi/ 2020 Volume 8 Number 1 (September) http://doi.org/10.9770/jesi.2020.8.1(1)

receiving and goods issue, and the time of waiting for shipment (Matwiejczuk, 2014). The time of all those activities decides on the efficiency of the warehouse. Material handling is characterised by high dynamic (Ellram \& Ueltschy Murfield, 2019).

The main purpose of logistics processes is ensuring the highest level of customer service, having the lowest possible costs (Grzybowska, 2010). There are various modern strategies of stock management, which are to lower the costs of a company through decreasing stock, and at the same time, keeping the standards of customer service (Banaszak, Kłos, Mleczko, 2011). However, quickly changing demand and the possible costs for companies resulting from the lack of stock, prevent the elimination of the storage process. That is why warehouse space is still one of the most important links in the logistics process of every enterprise (Blaik, 2013).

On the one hand storage is a necessary activity, but on the other it is very expensive. The quest for limiting the complex cost of storing has generated a demand for, and following it creation of, a completely new kind of enterprises and warehouse services (Coyle, Bardi, Langley, 2010). Nowadays, these services take two main forms: the provision of commissioned storage services and providing storage space. In the first case, a warehouse company takes care of the cargo and the realization of all the main and supplementary services. In the second case, the service provider puts at disposal only a warehouse space with its equipment. From a formal point of view, this service is a classical rental service (Sainathuni et al., 2014; Mickleson et al., 2019). The basic criterion allowing to distinct modern warehouse spaces is their purpose and usage to the realization of commercial services which are commissioned and undertaken against payment for a recipient (Brockmann, Godin, 1997).

The development of modern warehouse spaces in Poland takes place faster than in the other countries of Central and Eastern Europe (Kisperska-Moron, 1999; Richards 2014). The first objects of this type appeared in the first half of the nineties. At that time both developers and investors concentrated on Warsaw and its neighbourhood. The uncertain political and economic situation, poor state of transport infrastructure and little demand discouraged investors from performing in the other parts of Poland (Długosz, 2009; Kern et al., 2020).

The situation changed in the years 2004 - 2005, when the accession of Poland to the European Union initiated a sudden growth of commercial investments. Following the increasing demand, the developers more willingly started investing also outside Warsaw.

Sustainable development aspects are also important when creating warehouse space (Tseng et al., 2019). Solutions leading to obtaining ecological certificates are used more and more often (Atieh et al., 2016; Alawneh \& Zhang, 2018). The way to obtain them is to use the BREEAM (Building Research Establishment Environmental Assessment Method) and LEED (Leadership in Energy and Environmental Design) systems. Sustainable construction in the area of warehouse space allows for the creation of friendly work environments and leads to the optimization of costs associated with the operation of objects (Chen et al., 2016).

\section{Materials and methods}

The purpose of the study is an attempt to show the scope of diversity occurring in the warehouse space market in a regional system. The analysis of the warehouse space, the scope of its use, as well as the amount of rent were carried out including the split into the main regions of occurrence. The level of sector differentiation was also shown.

The volume of warehouse space was analyzed in relation to the total supply in the country and individual regions of concentration. The assessment of the increase and dynamics of warehouse space was made by main regions and development regions. 
The extent of use of warehouse space was assessed on the basis of the vacancy rate expressed as a percentage. It is the relation of vacant space to the total warehouse space in a given area.

Comparison of rents paid by tenants was made on the basis of base rates. Their height depends on the location of the object, its equipment and specifics. An important factor is also the size of the offered space and the estimated rental time. It is worth observing that the effective rates are, on average, lower by $25 \%-35 \%$ than the base rates. The main sources of information were reports prepared by consulting companies, trade press and source literature.

\section{Results and disscussion}

The developing warehouse market has turned out to be very vulnerable to economic turmoil. In 2008 the fall in demand for renting warehouse space resulted in the decrease in concluded contracts, and consequently the decrease in the implemented and planned investments, which created a supply restriction concerning new investments. It was still possible to observe this situation at the beginning of 2010. However, since mid-2010 one could notice a significant revival connected with the improvement of the market situation (see Fig. 1).

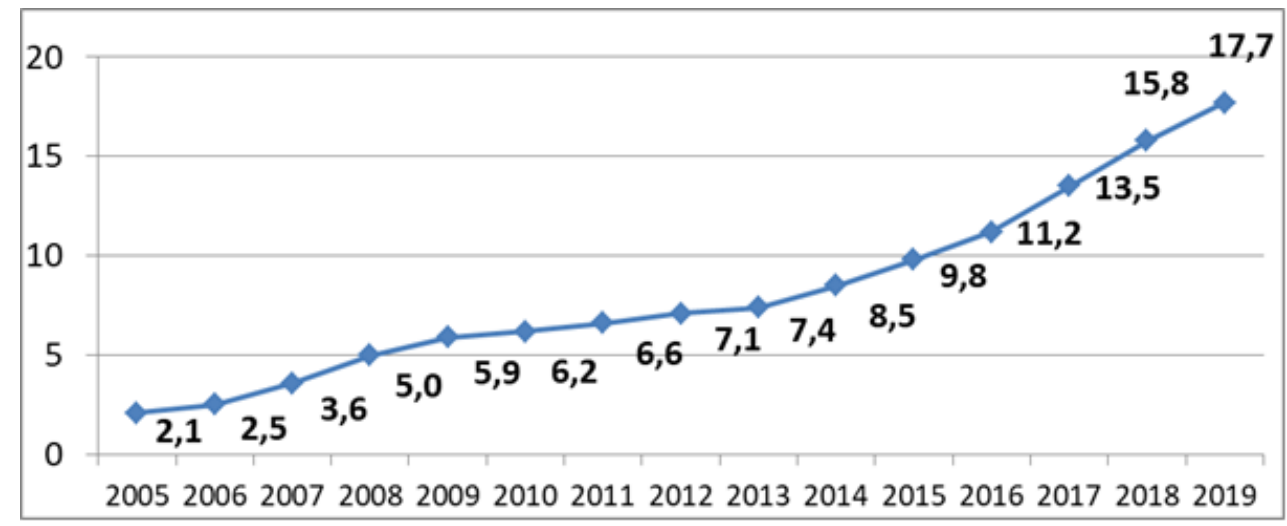

Fig. 1. Changes in the size of warehouse space in Poland in 2005-2019, in millions square meters (2019 - data for three quarters of the year)

Source: Own calculation based on reports The market of warehouse properties in Poland for each year (elaborated by JLL and Cushman \& Wakefield)

In Poland the years 2005-2008 were the period of an investment boom in the warehouse space market (Fig.1.). Industrial developers handed over to tenants huge amount of modern warehouses grouped in warehouse centres located in the neighbourhood of highways and expressways in the process of being built. At the end of 2008 the size of warehouse space amounted to $5 \mathrm{mln} \mathrm{m} 2$.

In 2010-2011 the market of modern warehouse space did not keep pace with the growth from the previous years (Droździecki, 2012). In 2010 the total increment of new areas was 326 thousand $\mathrm{m} 2$, and in 2011, 371 thousand $\mathrm{m} 2$. The year 2012 was much better, when 518 thousand $\mathrm{m} 2$ of new warehouse space were handed over to tenants (Fig. 2). In this way Poland became the biggest warehouse space market in Central and Eastern Poland. 


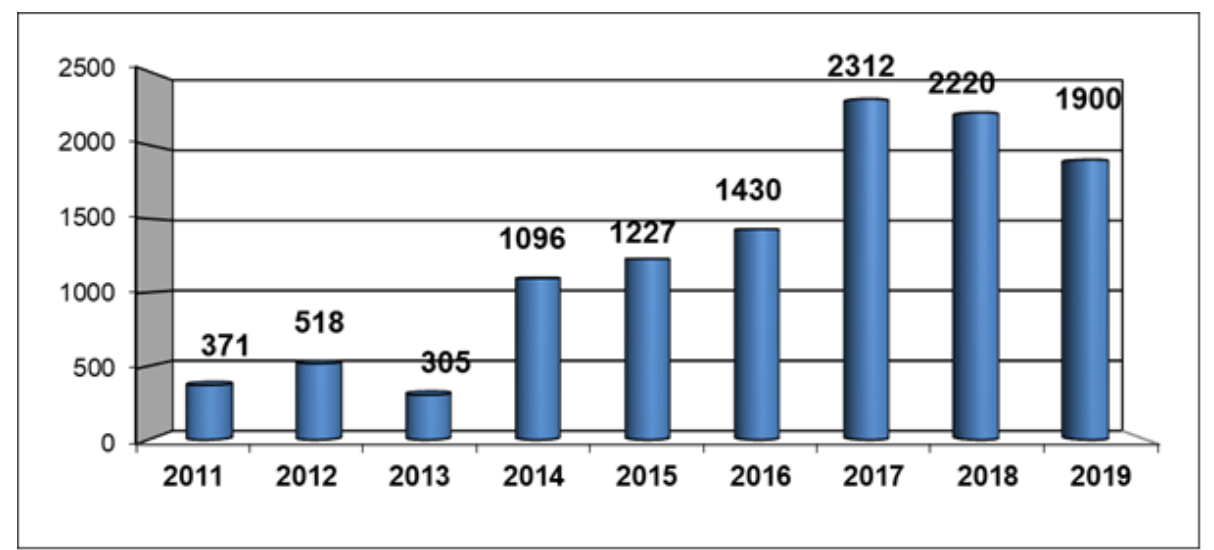

Fig. 2. The scope of change in the supply of warehouse space in Poland in 2011-2019, in millions square meters (2019 - data for three quarters of the year)

Source: Own calculation based on reports The market of warehouse properties in Poland for each year (elaborated by JLL and Cushman \& Wakefield)

The second wave of economic slowdown that reached Poland in 2012/2013 also affected the results of the warehouse sector. In 2013 the GDP increased by only 1.6\%, and the economic dynamic was as low as in 20082009. During the whole year 2013 only 305 thousand $\mathrm{m} 2$ of warehouse space were put into service, which earlier was quite a modest result.

At the end of 2014 the total supply of modern warehouse space amounted to $8.5 \mathrm{mln} \mathrm{m} 2$ and was the biggest among Central and Eastern European countries (Bond, 2015). During that year the activity of developers was high, resulting in putting into service over $1 \mathrm{mln} \mathrm{m} 2$. In 2014, $47 \%$ of the new supply was built within the projects such as BTS (build to suit). The new areas concentrated in five main regions, which embraced $92 \%$ of total supplies.

In 2015 the Polish economy one more time got very good results. GDP increased by $3.6 \%$ and the unemployment rate decreased further, falling below 10\%. At the end of 2015 the total supply in the Polish warehouse space market was $9.5 \mathrm{mln} \mathrm{m} 2.774,000 \mathrm{~m} 2$ were under construction within 33 different investment projects. The area around Warsaw was the leader, where 219,000 m2 warehouse space was created (Fechner, Szyszka, 2018).

At the end of 2016 the total supply of warehouse space amounted to $11.2 \mathrm{mln} \mathrm{m} 2$ and during one year rose by 1.4 mln $\mathrm{m} 2$. It was an increase by $15 \%$ year-over-year with the higher dynamic mainly in regional markets. The year 2017 turned out to be a peak year (Rajska-Wolińska, 2018), when $2.3 \mathrm{mln} \mathrm{m} 2$ of the new warehouse space appeared in the market, and the total supply reached $13.5 \mathrm{mln} \mathrm{m} 2$.

In 2018, with a good economic situation one could observe a high demand and a great supply in the Polish warehouse sector. The demand from tenants was $4 \mathrm{mln} \mathrm{m} 2$, from which new lease agreements and expansions consisted of $72 \%$. The developers completed over $2.2 \mathrm{mln} \mathrm{m} 2$ of the new warehouse space, only $8 \%$ less than in 2017. At the end of that year the impressive number of $1.9 \mathrm{mln} \mathrm{m} 2$ were under construction, more by $37 \%$ compared with the same period in 2017.

At the end of the third quarter of 2019 the total supply of the new warehouse space was $17.7 \mathrm{mln} \mathrm{m} 2$. This was the result of commissioning $1.9 \mathrm{mln} \mathrm{m} 2$ since the beginning of that year, and the investments completed in the third quarter amounted to $990,000 \mathrm{~m} 2$. This result was higher by $56 \%$ than the analogous outcome the previous year. At the end of September, 54\% of warehouses under construction were not secured by lease agreements, which is evidence of the developers' optimistic approach concerning the future of the market. 


\section{ENTREPRENEURSHIP AND SUSTAINABILITY ISSUES}

ISSN 2345-0282 (online) http://jssidoi.org/jesi/ 2020 Volume 8 Number 1 (September) http://doi.org/10.9770/jesi.2020.8.1(1)

The regions embracing the so called Great Five, that is Warsaw, Upper Silesia, Central Poland, Poznań and Wrocław, have been the pillars of the Polish warehouse market since the very beginning of modern warehouse space creation. The total share of these locations in the demand in 2013 was $90 \%$, and in supply amounted to 92 $\%$. In 2014 - 2019 Central Poland turned out to be the fastest developing region (Table 1), where the supply of warehouse space increased by $135 \%$. Equally intensive development occurred, in that period, in Upper Silesia, where $1.6 \mathrm{mln} \mathrm{m} 2$ warehouse space were created.

Table 1. The change in the warehouse space market in 2014-2019 in the main regions, in thousands square meters (2019 - data for three

\begin{tabular}{|l|r|r|r|r|r|r|r|r|}
\hline $\begin{array}{c}\text { Main } \\
\text { regions }\end{array}$ & $\mathbf{2 0 1 4}$ & $\mathbf{2 0 1 5}$ & $\mathbf{2 0 1 6}$ & $\mathbf{2 0 1 7}$ & $\mathbf{2 0 1 8}$ & $\mathbf{2 0 1 9}$ & \multicolumn{1}{|c|}{$\begin{array}{c}\text { Increase } \\
\text { Dynamics in }\end{array}$} & $\begin{array}{c}\text { Dyna14 } \\
\text { \%019/2014 }\end{array}$ \\
\hline Warsaw City & 596,0 & 605,0 & 653,0 & 693,0 & 765,0 & 778,0 & 182,0 & 130,5 \\
\hline Warsaw Around & 2079,0 & 2295,0 & 2511,0 & 2933,8 & 3149,0 & 3339,0 & 1260,0 & 160,6 \\
\hline Upper Silesia & 1545,0 & 1701,0 & 1955,0 & 2394,3 & 2764,0 & 3235,0 & 1690,0 & 209,4 \\
\hline Poznań & 1267,0 & 1587,0 & 1806,0 & 1941,9 & 2022,0 & 2044,0 & 777,0 & 161,3 \\
\hline Central Poland & 1239,0 & 1298,0 & 1565,0 & 1713,6 & 2544,0 & 2917,0 & 1678,0 & 235,4 \\
\hline Wroclaw & 1162,0 & 1270,0 & 1394,0 & 1633,4 & 1791,0 & 2004,0 & 842,0 & 172,5 \\
\hline
\end{tabular}

Source: Own calculation based on reports The market of warehouse properties in Poland for each year (elaborated by JLL and Cushman \& Wakefield)

In spite of the dominating position of the five locations, their share in demand in 2018 decreased to $74 \%$, and the share in total supplies to $83 \%$. This is, first of all, the result of increasing transport availability translated into logistics and production investments (Sinkiewicz, Semaan, 2019). Also, as the unemployment rate fell, a new asset of local staff reserve appeared especially in smaller towns. The cost of land, which is lower than around main agglomerations, is also not without significance. The years 2016-2019 turned out to be a very prosperous period also for Szczecin. This city, already having a good road connection with Germany, strengthened its attractiveness when the S3 expressway towards the south of Poland, and the S6 expressway towards Koszalin were completed. The entrance into the market of two e-commerce companies (Amazon from the USA and Zalando from Germany) became a turning point, and Szczecin appeared in the list of the most attractive locations for warehouse space in Poland. Those two investments were realized mainly to fulfill the plan of serving Western Europe markets (especially in Germany and Scandinavian countries). As a result the warehouse space market increased then from 187,000 $\mathrm{m} 2$ to $711,000 \mathrm{~m} 2$ (Fig.3).

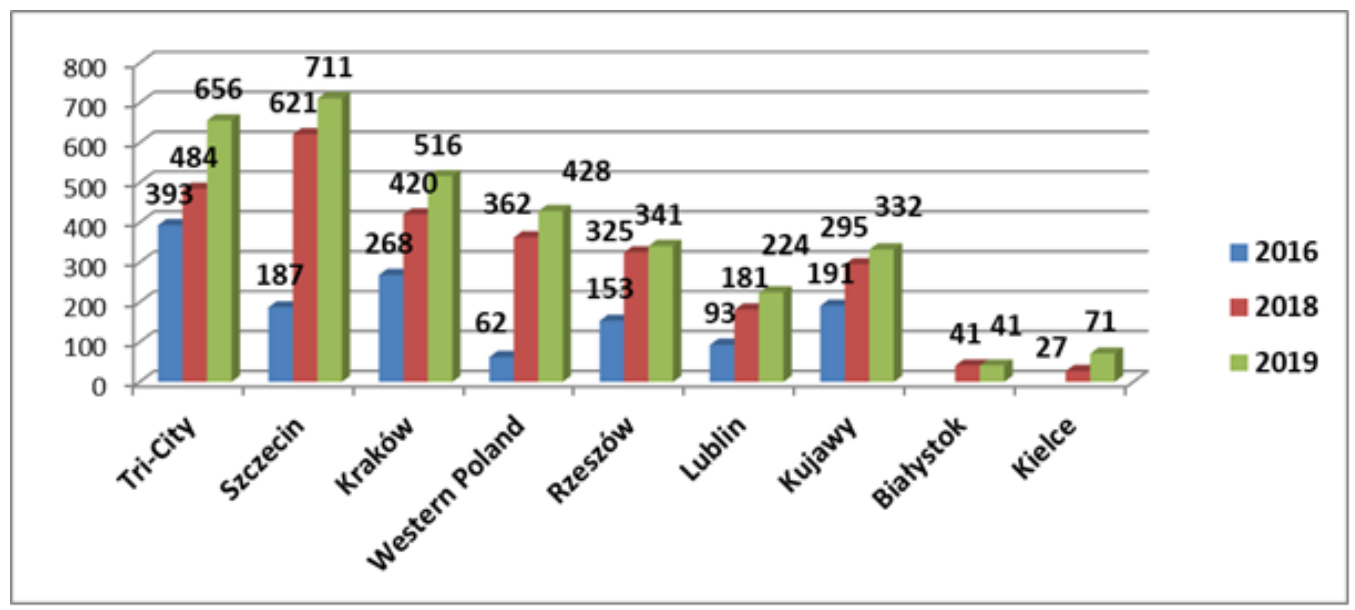

Fig. 3. The change in the warehouse space market in 2016-2019 in the developing regions, in thousands square meters (2019 - data for three quarters of the year)

Source: Own calculation based on reports The market of warehouse properties in Poland for each year (elaborated by JLL and Cushman \& Wakefield) 


\section{ENTREPRENEURSHIP AND SUSTAINABILITY ISSUES}

ISSN 2345-0282 (online) http://jssidoi.org/jesi/ 2020 Volume 8 Number 1 (September) http://doi.org/10.9770/jesi.2020.8.1(1)

A similar group of factors stimulated the development of the warehouse space market in the region of Western Poland. This is a young warehouse market with a big development potential, extending along the S3 expressway and embracing, among others, Gorzów Wielkopolski, Świebodzin, Zielona Góra, Zgorzelec and Legnica. Because of its strategic location near the German and Czech Republic markets, this region attracts more and more attention of companies connected with such branches as: production, automotive, logistics and e-commerce (Dittmann, 2016). At the end of the third quarter of 2019 total supplies of warehouse space in this region were $428,000 \mathrm{~m} 2$. Western Poland is a specific region where the vacancy rate has been standing at zero level for a long time. This is due to the fact that most of the projects realized in this market are BTS (build to suit) investments.

The years 2017 - 2019 are the period of a clear increase in developers' and tenants' activities in the Eastern Poland warehouse market. One can observe the revival, both in maturing warehouse markets, such as Lublin or Rzeszów, and the new locations, such as Kielce and Białystok. In 2018, the first large investments were precisely in the latter two locations. Completing subsequent sections of expressways such as the S8 (Warsaw - Białystok) and construction of the S17 route, the section Warsaw - Lublin, as well as finalizing work in the S7 Warsaw Kielce section, influence the growth of logistics potential of cities in Eastern Poland. Also, the situation in the local labour market is an important factor. According to Manpower data, the recruitment of 100 staff of a production company is the shortest in Białystok, and lasts about 40 days. This process takes 50 days in Rzeszów, Częstochowa, Lublin, Gorzów and Kalisz. In Wrocław, Warsaw and its neighbourhood as well as in Poznań the recruitment of employees lasts the longest - 90 days (Olszewski, Michalak, 2019). The afore-mentioned conditions mean that the warehouse space market in Eastern Poland in 2016 - 2019 doubled its supplies approaching 700,000 m2. The main credit for the situation goes to two cities: Rzeszów and Lublin.

The interplay of infrastructure factors, which already exist and these being in the implementation phase, appeared in Bydgoszcz and Torun. These two biggest cities of the Kujawsko-Pomorskie Voivodeship, located near the completed A1 highway, the S5 expressway (Ostróda-Wrocław) being under construction, and the S10 route (Szczecin - Wołomin near Warsaw), also doubled the supplies of warehouse space (growth from 161, 000 to 332, $000 \mathrm{~m} 2)$ in $2016-2019)$.

Remaining at a high level demand for warehouse space combined with moderately increasing supply secured by lease agreements contributed to reducing the vacancy rate (Haber, 2017). This indicator gradually decreased from 2014 reaching a record low level of 5\% at the end of 2018 (Table 2).

Table 2. The change in the vacancy rate in 2014 - 2019 in regions, in percentage (2019 - data for three quarters)

\begin{tabular}{|l|r|r|r|r|r|r|r|}
\hline $\begin{array}{c}\text { Main } \\
\text { regions }\end{array}$ & \multicolumn{1}{c|}{$\mathbf{2 0 1 4}$} & $\mathbf{2 0 1 5}$ & $\mathbf{2 0 1 6}$ & $\mathbf{2 0 1 7}$ & $\mathbf{2 0 1 8}$ & $\mathbf{2 0 1 9}$ & $\begin{array}{c}\text { Increase/ } \\
\text { decrease in } \\
\text { percentage points }\end{array}$ \\
\hline Warsaw City & 14,6 & 10,4 & 9,4 & 9,5 & 9,2 & 12,6 & $-2,0$ \\
\hline Warsaw Around & 10,2 & 8,7 & 5,5 & 4,9 & 3,8 & 4,1 & $-6,1$ \\
\hline Upper Silesia & 11,1 & 7,4 & 7,2 & 5,1 & 5,7 & 6,6 & $-4,5$ \\
\hline Poznań & 2,5 & 1,9 & 7,2 & 7,5 & 8,7 & 8,3 & $-9,8$ \\
\hline Central Poland & 18,6 & 6,4 & 4,1 & 0,2 & 5,0 & 8,7 & $-1,4$ \\
\hline Wroclaw & 5,7 & 5,8 & 5,1 & 6,6 & 2,6 & 4,3 & $-3,6$ \\
\hline Total Poland & 9,8 & 6,2 & 6,1 & 5,4 & 5,0 & 6,2 & \\
\hline
\end{tabular}

Source: Own calculation based on reports The market of warehouse properties in Poland for each year (elaborated by JLL and Cushman \& Wakefield)

In 2019 the vacancy rate increased to reach $6.2 \%$. The relatively high share of speculatively built warehouse space that could be observed in recent quarters resulted in the low growth of rented warehouse space throughout the country. This is visible mainly in smaller markets with limited demand, where even single speculative warehouses put into service significantly affect the vacancy rate (Głowacz, Rykowska, Staśkiewicz-Wieczorek, 2019). In the 


\section{ENTREPRENEURSHIP AND SUSTAINABILITY ISSUES}

ISSN 2345-0282 (online) http://jssidoi.org/jesi/ 2020 Volume 8 Number 1 (September) http://doi.org/10.9770/jesi.2020.8.1(1)

main markets the highest rate was in Warsaw (12.6\%) and Central Poland (8.7\%), followed by the Poznań region (8.3) and Upper Silesia (6.6).

The warehouse market in Poznań is characterised by a relatively high availability of warehouse space. This translates into high competitiveness among developers, which has a positive impact on the negotiating position of the future tenants. The remaining low vacancy rate in the Warsaw area (4.1\%), combined with record demand and further development of transport infrastructure promote the realization of new projects in this market. The progression of the S7 and the S8 interchange with the Warsaw bypass create new opportunities for the development of big projects, such as BIG-BOX, as well as smaller ones, contributing to city logistics. In many cases (especially in the new areas being discovered by developers), the availability of a relatively inexpensive warehouse space of class A, encourages tenants to leaving the already rented old places and moving to new locations (Polkowski, Kotowski, 2019).

The ownership structure remains without any major change. Almost 50\% of resources belong to the five main players, that is Panattoni, Prologis, Segro, Logicor, Mapletree and their partners. P3 and Goodman each posses $5 \%$ of the share in the ownership structure.

Developers more and more often ensure that warehouses are equipped with a number of ecological systems in the field of sustainable development (Badi \& Murtagh, 2019; Tumpa et al., 2019). These systems control water consumption and save energy for air conditioning and ventilation (Fikiin et al., 2017; Geyi et al., 2019). Modern lighting and heating and cooling systems allow for significant savings in terms of media consumption throughout the building (Mahroof, 2019).

Guided by the idea of sustainable development, Panattoni built two BTS facilities for H\&M in Grodzisk Mazowiecki and in Gądki near Poznań. They obtained LEED system certificates at Silver level. The ecological nature of the investment for $H \& M$ is proved by modern design of the warehouse, the use of ecological materials, energy efficiency, as well as the right location (Feng et al., 2017).

Also SEGRO introduced a number of changes in the standard of construction of its warehouses. The developer focused on innovative, ecological solutions in its strategy. According to its assumptions, every newly created SEGRO facility is certified in the BREEAM system. An example of this type of facility is the distribution center in Komorniki near Poznań. In a building with an area of 32 thousand. $\mathrm{m} 2$ of warehouse space, among others, intelligent LED zone lighting controlled by motion sensors (Halawa et al., 2019; Lyu et al., 2020). Special water distribution systems have been used in the facility to reduce water consumption by up to 10 percent (Monthatipkul \& Yenradee, 2008).

There is a big differentiation of industries and sectors of companies' activities among the tenants of warehouse space (Fig.4). 


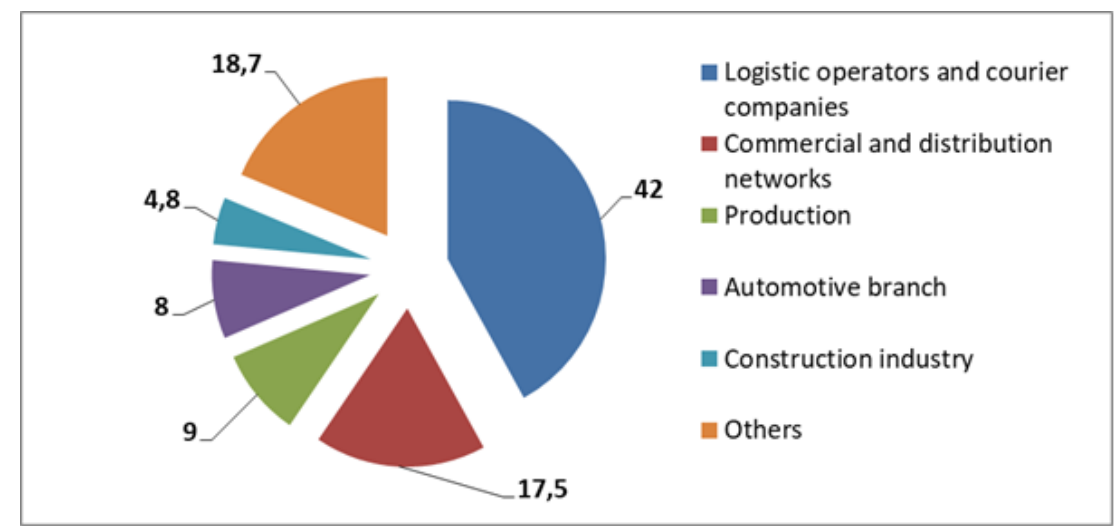

Fig. 4. Demand according to sectors in 2019 (III quarter) in percentage

Source: Own calculation based on reports The market of warehouse properties in Poland for each year (elaborated by JLL and Cushman \& Wakefield)

Traditional companies from the logistics sector, delivery firms and retail chains had the biggest share in the industry structure of the warehouse space tenants. They rented $59.5 \%$ of the total area in the third quarter of 2019. Also the sectors of light production and automotive showed an impressive activity during the first three quarters of 2019 being responsible for over one fifth of the demand.

An important factor conditioning the locations of distribution centres for retail chains is the geographical position of the points of sale. Research shows that the cost of transport amounts to 50\% of the supply chain costs, while rent is just above $4 \%$. The right choice of location of a warehouse is of key importance for the financial success of the companies (Olszewski, Michalak, 2019).

Similarly to previous quarters, the tenants who are already present in the Polish market and who, thanks to new logistics contracts, invest in renting modern warehouse space to adjust their supply chain to serve e-commerce channel, gain advantage in the demand structure (Majewski, 2016). This situation concerns big players, including operators and retail chains, and medium sized companies, which decide to improve the standard of their warehouses and move to modern distribution centres (Krawczyk, 2011).

The scope of rent for warehouse space differentiation in $2014-2019$ is presented in Table 3.

Table 3. The levels of rent in the warehouse market in $2014-2017$, according to regions, in Euro

\begin{tabular}{|l|c|c|c|c|c|c|}
\hline \multicolumn{1}{|c|}{ Regions } & $\mathbf{2 0 1 4}$ & $\mathbf{2 0 1 5}$ & $\mathbf{2 0 1 6}$ & $\mathbf{2 0 1 7}$ & $\mathbf{2 0 1 8}$ & $\mathbf{2 0 1 9}$ \\
\hline Warsaw City & $4,10-5,50$ & $4,10-5,30$ & $4,10-5,10$ & $3,50-5,50$ & $4,30-5,25$ & $4,30-5,25$ \\
\hline Warsaw Around & $2,70-3,60$ & $2,70-3,60$ & $2,70-3,60$ & $2,00-3,20$ & $2,50-3,60$ & $2,60-3,80$ \\
\hline Upper Silesia & $3,00-3,70$ & $2,80-3,50$ & $2,70-3,60$ & $2,20-3,20$ & $2,90-3,60$ & $2,90-3,60$ \\
\hline Poznań & $2,90-3,50$ & $2,80-3,50$ & $2,80-3,50$ & $2,00-3,20$ & $3,00-3,50$ & $2,90-3,50$ \\
\hline Central Poland & $2,10-2,80$ & $2,60-3,30$ & $2,60-3,20$ & $2,00-3,20$ & $2,40-3,60$ & $2,50-3,60$ \\
\hline Wroclaw & $3,00-3,60$ & $3,00-3,60$ & $2,80-3,60$ & $2,60-3,60$ & $3,00-3,60$ & $3,00-3,60$ \\
\hline Kraków & $4,00-4,80$ & $3,60-4,20$ & $3,50-4,20$ & $3,50-4,50$ & $3,00-4,20$ & $3,20-4,30$ \\
\hline Tri-City & $3,00-3,50$ & $2,80-3,20$ & $2,80-3,35$ & $2,80-3,50$ & $3,00-3,50$ & $3,10-3,60$ \\
\hline Szczecin & $3,00-3,75$ & $2,70-3,40$ & $3,20-3,70$ & $3,20-3,50$ & $3,20-3,50$ & $3,20-3,50$ \\
\hline
\end{tabular}

Source: Own calculation based on reports The market of warehouse properties in Poland for each year (elaborated by JLL and Cushman \& Wakefield)

The rent base rate in 2014 - 2019 was relatively stable with a weak tendency getting lower. The upward trend appeared in the first three quarters of 2019 in chosen locations, such as Warsaw and its neighbourhood, and 
Kraków. This was connected with a higher cost of land and growing prices of building materials. However, in highly competitive markets, where the availability of warehouse space is increasing, the rent shows a downward trend.

The highest base rent invariably appears in the Warsaw market, especially within the city, where the rates vary from 4.30 to 5.25 Euro for $\mathrm{m} 2$, per month. This results from this market specifics, where most warehouse space is not big, below $4-5$ thousand square meters. Base rents in the other warehouse markets are $2.60-3.80$ Euro for a square meter per month in the case of larger module type Big-box.

It is worth observing that the effective rates are, on average, lower by $25 \%-35 \%$ than the base rates presented in Table 3. The lowest rates, both base and effective, are likely to be paid in the Warsaw area, Central Poland and Poznań. The growth of warehouse space, resulting from very high demand, strengthens the negotiation power of tenants. This situation creates opportunities for renting warehouse space for $2.10-3.20$ Euro for a square meter per month.

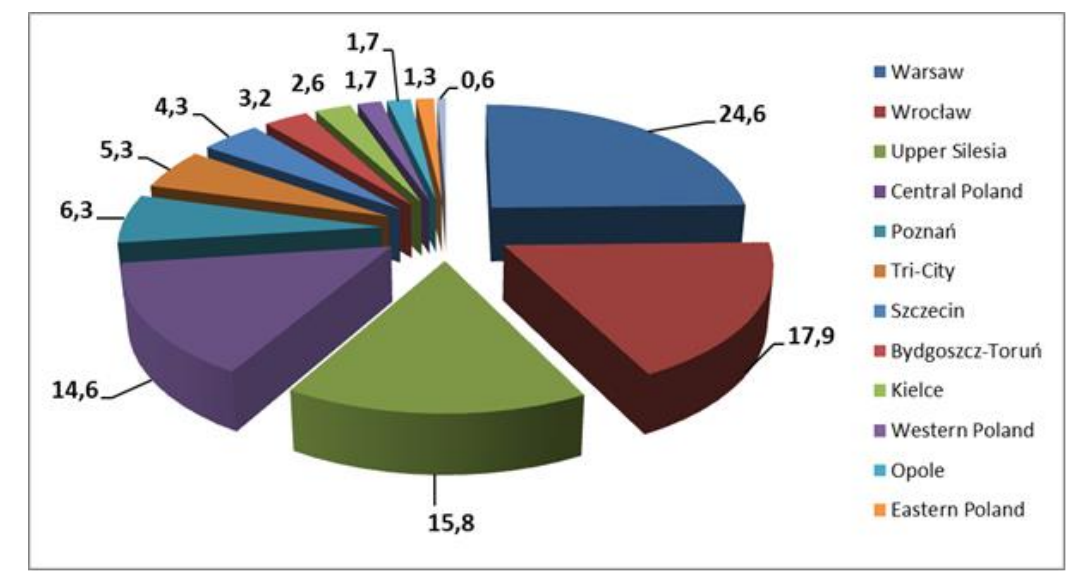

Fig. 5. The structure of warehouse space being under construction in the third quarter of 2019, in Poland, in percentage Source: Own calculation based on reports The market of warehouse properties in Poland for each year (elaborated by JLL and Cushman \& Wakefield)

The total amount of warehouse space under construction is not slowing down the activities of developers. At the end of 2019, as much as $1.9 \mathrm{mln} \mathrm{m} 2$ were under different stages of construction. The most warehouse space is built in the Warsaw region, 456,000 m2, next in Lower Silesia, 330,00 m2 and Upper Silesia 298,00 m2. Totally, almost $80 \%$ of warehouse space is in the Great Five markets (79.2\%). The most active markets, except those afore-mentioned, are Tri-City, Szczecin, Kujawy and Kielce (Fig. 5).

The fact that only two out of ten projects under construction were rented in the whole by concrete companies (the warehouse in Mszczonów by Pepsico and the warehouse in Rawa Mazowiecka by Carrefour) confirms the developers' optimism. This transfers into over $1 \mathrm{mln} \mathrm{m} 2$ built speculatively. However, taking into consideration demand in the market, one can expect that a large part of the warehouse space will be rented still at the construction state.

\section{Conclusions}

In Poland the amount of warehouse space is increasing every year. In 2014 it exceeded $8.5 \mathrm{mln} \mathrm{m} 2$ and in the third quarter of 2019 amounted to $17.7 \mathrm{mln} \mathrm{m} 2$. Hundreds of thousands of square meters of these new areas have 


\section{ENTREPRENEURSHIP AND SUSTAINABILITY ISSUES}

ISSN 2345-0282 (online) http://jssidoi.org/jesi/ 2020 Volume 8 Number 1 (September) http://doi.org/10.9770/jesi.2020.8.1(1)

been put into service. Nowadays, $83 \%$ of the warehouse space market is in five progressive regions (the Warsaw region, Upper Silesia, Wrocław and the Poznań region). These centres are densely populated and itself generate high demand for goods being produced in companies, but also stored in warehouses. At the same time developers and tenants show more and more interest in the new progressing locations, especially in the regions around Szczecin, Tri-City, Rzeszów and Lublin.

The changes to date in the demand for warehouse space create good perspectives for the development of this market in Poland. E-commerce and the expansion of strategic for the Polish economy industries, such as automotive, food and household goods are responsible for the still growing interest in renting warehouse space. Logistics outsourcing is also an important factor.

Many tenants of warehouse space want to use environmentally friendly buildings. There are more and more facilities with ecological certificates on the market. Developers such as Panattoni and Segro offer facilities compatible with sustainable construction. An ecological warehouse is in many cases pure profit. It means not only lower water and energy bills, but also helps to improve the company's image.

Because of further development of the transport infrastructure and the decreasing availability of qualified employees in bigger agglomerations, the developers' activities will be increasingly moved to smaller markets and medium sized towns such as Olsztyn, Elbląg, Częstochowa, towns in Eastern Poland and also locations by the Western border. The difference in the levels of employee salaries and the availability of land at an attractive price, influence the growth of investment potential.

The increasing purchasing power of Polish citizens, which accelerates retail sale, both in a traditional way and through the Internet, also indicates a favourable outlook for the development of the warehouse space market, because this translates into the demand for the organization of distribution centres with the usage of logistics areas.

In terms of the market size, Poland ranks 7th in the European Union. Taking into consideration the already existing square meters compared with the population and GDP, and comparing that with the Western European countries, it turns out that there is still a huge potential for further development.

\section{References}

Alawneh, F., \& Zhang, G. (2018). Dual-channel warehouse and inventory management with stochastic demand. Transportation Research Part E: Logistics and Transportation Review, 112, 84-106. https://doi.org/https://doi.org/10.1016/j.tre.2017.12.012

Atieh, A. M., Kaylani, H., Al-abdallat, Y., Qaderi, A., Ghoul, L., Jaradat, L., \& Hdairis, I. (2016). Performance Improvement of Inventory Management System Processes by an Automated Warehouse Management System. Procedia CIRP, 41, 568-572. https://doi.org/https://doi.org/10.1016/j.procir.2015.12.122

Badi, S., \& Murtagh, N. (2019). Green supply chain management in construction: A systematic literature review and future research agenda. Journal of Cleaner Production, 223, 312-322. https://doi.org/https://doi.org/10.1016/j.jclepro.2019.03.132

Banaszak, Z., Kłos, S., Mleczko, J. (2011). Zintegrowane systemy zarządzania (Itegrated management systems), PWE, Warszawa.

Ben Moussa, F. Z., De Guio, R., Dubois, S., Rasovska, I., \& Benmoussa, R. (2019). Study of an innovative method based on complementarity between ARIZ, lean management and discrete event simulation for solving warehousing problems. Computers \& Industrial Engineering, 132, 124-140. https://doi.org/https://doi.org/10.1016/j.cie.2019.04.024

Blaik, P. (2013). Logistyka w systemie zarządzania przedsiębiorstwem (Logistics in the enterprise management system), PWE, Warszawa. 


\section{ENTREPRENEURSHIP AND SUSTAINABILITY ISSUES}

ISSN 2345-0282 (online) http://jssidoi.org/jesi/ 2020 Volume 8 Number 1 (September) http://doi.org/10.9770/jesi.2020.8.1(1)

Bond, J. (2015). Top 20 3PL and Public Refrigerated Warehouses. Special Report, Modern Materials Handling, No 12

Brockmann, T., Godin, P. (1997). Flexibility for the Future in Warehouse Design, HE Solutions, No 7.

Chen, X., Wang, X., Kumar, V., \& Kumar, N. (2016). Low carbon warehouse management under cap-and-trade policy. Journal of Cleaner Production, 139, 894-904. https://doi.org/https://doi.org/10.1016/j.jclepro.2016.08.089

Coyle, J., Bardi, E., Langley, C. Jr. (2010). Zarządzanie logistyczne (Logistics management), PWE, Warszawa 2010.

Dittmann, P. (2016). 11 ways to optimize your warehouse, Industrial Engineer, No 2.

Długosz, J. (2009). Nowoczesne technologie w logistyce (Modern technologies in Logistics), PWE, Warszawa 2009.

Dołęga, S, (2019), Rynek magazynowy w 2019 idzie na rekord (The warehouse market in 2019 is breaking the record), Retrieved from: www.terenyinwestycyjne.info/wiadomosci/magazyny-1/rynek-magazynowy-w-2019-idzie-na-rekord

Droździecki, S. (2012). Nowoczesne powierzchnie magazynowe w kształtowaniu funkcji logistycznych aglomeracji Trójmiasta (Modern warehouse space in shaping the logistics functions of the Tri-City agglomeration), Logistyka nr 2.

Ellram, L. M., \& Ueltschy Murfield, M. L. (2019). Supply chain management in industrial marketing-Relationships matter. Industrial Marketing Management, 79, 36-45. https://doi.org/https://doi.org/10.1016/j.indmarman.2019.03.007

Fechner, I., Szyszka, G. (2018). Logistyka w Polsce. Raport 2017 (Logistics in Poland. 2017 report). Biblioteka Logistyka. Poznań.

Feng, X., Moon, I., \& Ryu, K. (2017). Warehouse capacity sharing via transshipment for an integrated two-echelon supply chain. Transportation Research Part E: Logistics and Transportation Review, 104, 17-35. https://doi.org/https://doi.org/10.1016/j.tre.2017.04.014

Fikiin, K., Stankov, B., Evans, J., Maidment, G., Foster, A., Brown, T., Radcliffe, J., Youbi-Idrissi, M., Alford, A., Varga, L., Alvarez, G., Ivanov, I. E., Bond, C., Colombo, I., Garcia-Naveda, G., Ivanov, I., Hattori, K., Umeki, D., Bojkov, T., \& Kaloyanov, N. (2017). Refrigerated warehouses as intelligent hubs to integrate renewable energy in industrial food refrigeration and to enhance power grid sustainability. Trends in Food Science \& Technology, 60, 96-103. https://doi.org/https://doi.org/10.1016/j.tifs.2016.11.011

Galińska, B. (2016). Gospodarka magazynowa (Warehouse management), Difin, Warszawa.

Geyi, D. G., Yusuf, Y., Menhat, M. S., Abubakar, T., \& Ogbuke, N. J. (2019). Agile capabilities as necessary conditions for maximising sustainable supply chain performance: An empirical investigation. International Journal of Production Economics, 107501. https://doi.org/https://doi.org/10.1016/j.ijpe.2019.09.022

Głowacz, A. Rykowska, M. Staśkiewicz-Wieczorek B. (2019). Rynek magazynowy w III kwartale 2019 r. (Warehouse market in the third quarter of 2019) AXIMMO. Retrieved from: https://www.axiimmo.com/raporty-i-publikacje/raport-rynek-magazynowy-w-i-polowie-2019$\underline{\mathrm{r}}$

Grzybowska, K. (2010). Gospodarka zapasami i magazynem. (Inventory and warehouse management), Difin, Warszawa.

Haber, E. (2017). Nadal tendencje rozwojowe (Development trends continue). TSL Biznes nr 5.

Halawa, F., Dauod, H., Lee, I. G., Li, Y., Yoon, S. W., \& Chung, S. H. (2019). Introduction of a real time location system to enhance the warehouse safety and operational efficiency. International Journal of Production Economics, 107541. https://doi.org/https://doi.org/10.1016/j.ijpe.2019.107541

Kern, R., Kozierkiewicz, A., \& Pietranik, M. (2020). The data richness estimation framework for federated data warehouse integration. Information Sciences, 513, 397-411. https://doi.org/https://doi.org/10.1016/j.ins.2019.10.046

Kisperska-Moron, D. (1999). Warehousing conditions for holding inventory in Polish supply chains. International Journal of Production Economics, 59(1), 123-128. https://doi.org/https://doi.org/10.1016/S0925-5273(98)00233-3

Krawczyk S. (2011). Logistyka. Teoria i praktyka (Logistics. Theory and practice), Difin, Warszawa. 


\section{ENTREPRENEURSHIP AND SUSTAINABILITY ISSUES}

ISSN 2345-0282 (online) http://jssidoi.org/jesi/ 2020 Volume 8 Number 1 (September) http://doi.org/10.9770/jesi.2020.8.1(1)

Krzyżaniak, S., Niemczyk, A., Majewski, J., Andrzejczyk, P. (2014). Organizacja i monitorowanie procesów magazynowych (Organization and monitoring of warehouse processes), Biblioteka Logistyka, Poznań.

Lin, Q., Su, X., \& Peng, Y. (2018). Supply chain coordination in Confirming Warehouse Financing. Computers \& Industrial Engineering, 118, 104-111. https://doi.org/https://doi.org/10.1016/j.cie.2018.02.029

Lyu, Z., Lin, P., Guo, D., \& Huang, G. Q. (2020). Towards Zero-Warehousing Smart Manufacturing from Zero-Inventory Just-In-Time production. Robotics and Computer-Integrated Manufacturing, 64, 101932. https://doi.org/https://doi.org/10.1016/j.rcim.2020.101932

Mahroof, K. (2019). A human-centric perspective exploring the readiness towards smart warehousing: The case of a large retail distribution warehouse. International Journal of Information Management, 45, 176-190. https://doi.org/https://doi.org/10.1016/j.ijinfomgt.2018.11.008

Majewski, J. (2016). Systemowe zarządzanie magazynem (System warehouse management), Warszawska Grupa Wydawnicza, Warszawa.

Makaci, M., Reaidy, P., Evrard-Samuel, K., Botta-Genoulaz, V., \& Monteiro, T. (2017). Pooled warehouse management: An empirical study. Computers \& Industrial Engineering, 112, 526-536. https://doi.org/https://doi.org/10.1016/j.cie.2017.03.005

Matwiejczuk, K. (2014). Kompetencje logistyki w tworzeniu przewagi konkurencyjnej przedsiębiorstwa (Logistics competence in creating competitive advantage of the company), Wydawnictwo Uniwersytetu Opolskiego, Opole.

Mickleson, G., Thai, V. V, \& Halim, Z. (2019). The Influence of Responsibility Shift on Warehousing Performance: The Case of Australia. The Asian Journal of Shipping and Logistics, 35(1), 3-12. https://doi.org/https://doi.org/10.1016/j.ajsl.2019.03.002

Monthatipkul, C., \& Yenradee, P. (2008). Inventory/distribution control system in a one-warehouse/multi-retailer supply chain. International Journal of Production Economics, 114(1), 119-133. https://doi.org/https://doi.org/10.1016/j.ijpe.2007.12.010

Olszewski, T., Michalak, H. (2019). Small town big deal. Badanie potencjału nowych lokalizacji magazynowo-przemysłowych w Polsce (Small town big deal. Research on the potential of new warehouse and industrial locations in Poland). ILL Retrieved from: https://www.jll.pl/pl/trendy-i-analizy/badanie/small-town-big-deal-2019

Polkowski M., Kotowski M. (2019). Rynek magazynowy w Polsce III kwartale 2019 (Warehouse market in Poland Q3 2019). ILL Retrieved from: https://industrial.pl/aktualnosci/raporty/264-marketbeat-rynek-magazynowy-w-polsce-iii-kwartal-2019-r-raport

Rajska-Wolińska, M. (2018). Polska Market Insights. Raport roczny 2018. Colliers International Retrieved from: http://docs.colliers.pl/reports/Colliers_Raport-Market-Insights-2018.pdf

Reports The market of warehouse properties in Poland. Cushman \& Wakefield. Retrieved from: http://www.cushmanwakefield.pl/plpl/research-and-insight

Reports The market of warehouse properties in Poland. ILL Retrieved from: https://www.jll.pl/pl/trendy-i-analizy

Richards, G. (2014). Warehouses of the near future, Focus, No 10

Sainathuni, B., Parikh, P. J., Zhang, X., \& Kong, N. (2014). The warehouse-inventory-transportation problem for supply chains. European Journal of Operational Research, 237(2), 690-700. https://doi.org/https://doi.org/10.1016/j.ejor.2014.02.007

Singh, R. K., Chaudhary, N., \& Saxena, N. (2018). Selection of warehouse location for a global supply chain: A case study. IIMB Management Review, 30(4), 343-356. https://doi.org/https://doi.org/10.1016/j.iimb.2018.08.009

Sinkiewicz, J., Semaan, A. (2019). Marketbeat. Polski rynek magazynowy III kw. 2019 r (Marketbeat. Polish warehouse market Q3 2019). Cushman \&Wakefield

Szymonik, A., Chudzik, D. (2018). Logistyka nowoczesnej gospodarki magazynowej (Logistics of modern warehouse management). Dyfin, Warszawa.

Trzysło, T., (2019). Inwestycyjne rekordy w Polsce i Europie Środkowo - Wschodniej (Investment records in Poland and Central and Eastern Europe.. Retrieved from: www.terenyinwestycyjne.info /inwestycyine-rekordy-w-polsce-i-europie-srodkowo-wschodniej 


\section{ENTREPRENEURSHIP AND SUSTAINABILITY ISSUES}

ISSN 2345-0282 (online) http://jssidoi.org/jesi/ 2020 Volume 8 Number 1 (September) http://doi.org/10.9770/jesi.2020.8.1(1)

Tseng, M.-L., Wu, K.-J., Lim, M. K., \& Wong, W.-P. (2019). Data-driven sustainable supply chain management performance: A hierarchical structure assessment under uncertainties. Journal of Cleaner Production, $227,760-771$. https://doi.org/https://doi.org/10.1016/j.jclepro.2019.04.201

Tumpa, T. J., Ali, S. M., Rahman, M. H., Paul, S. K., Chowdhury, P., \& Rehman Khan, S. A. (2019). Barriers to green supply chain management: An emerging economy context. Journal of Cleaner Production, 236 , 117617. https://doi.org/https://doi.org/10.1016/j.jclepro.2019.117617

\section{Acknowledgements}

This research was carried out under the research theme No. 501/18/S financed from by a science grant provided by the Ministry of Science and Higher Education of Poland.

Adam MARCYSIAK (PhD) is the Doctor of Sciences at Siedlce University of Natural Sciences and Humanities, Faculty of Social Science, Research interests: regional development; sustainability; supply chain management, ORCID ID: orcid.org/0000-0002-3132-8565

Register for an ORCID ID https://orcid.org/register

Copyright (C) 2020 by author(s) and VsI Entrepreneurship and Sustainability Center This work is licensed under the Creative Commons Attribution International License (CC BY). http://creativecommons.org/licenses/by/4.0/

(c) (†) Open Access 